\title{
荷電粒子を用いたダイヤモンド状薄膜の形成
}

\author{
難 波 義 捷

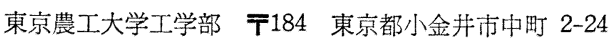 \\ (1984 年 9 月 10 日 受理)
}

\section{Diamondlike Carbon Films Prepared by Charged Particles}

\author{
Yoshikatsu NAMBA \\ Tokyo Noko University \\ 2-24, Nakacho, Koganei-shi, Tokyo 184
}

(Received September 10, 1984)

\begin{abstract}
The recent progress in diamondlike carbon films prepared by hydrocarbon ion or plasma gas are described. The typical systems reported are classified into three types such as plasma, ion, and neutral deposition systems and each system is discussed. Next, the physical properties and the crystal structures of these films are discussed in comparison with diamond powder. Finally, the growth process of diamond films in the case of ionized deposition is discussed based on the reported data.
\end{abstract}

\section{1. まえがき}

最近，プラズマまたはイオンを使用し，低圧下でダィ ヤモンド状薄膜を成長させる研究が大きな注目をあびて いる。この種の研究は，歴史的に見てそれ程古いことで はなく, 1971 年に Aisenbevg') がイオンビーム法によ りダイヤモンド状薄膜の成長することを発表したのが最 初である。それ以来, ダイヤモンド薄膜に関する研究は 非常に注目されるようになり，現在各国で行な利机るよ うになって来た。

ダイヤモンド薄膜が注目されている主な理由は，大き く分けて3つある。

第 1 はダイヤモンド薄膜の形成機構に関する問題であ る。既ち，ダイヤモンドの合成は，天然のものでも人工 的なものでも, 千数百度 $\left({ }^{\circ} \mathrm{C}\right)$ の高温之数万気圧の高圧が 必要とされており, また, 理論的にもこの問題はかなり 検討されている。したがって，あしダイヤモンドが低温 (数百度以下), 低圧 (大気圧以下) で合成できるとすれ ば，その合成機構をどのように考えるか，また従来の理 論との関係はどうか，という合成機構に関する理論的な 問題である。

第 2 は工業的な面である。即ち, ダイヤモンドは極め て硬いというとと以外に, 絶縁物でありながら熱伝導度 は非常に大きく, 光学的には紫外から赤外まで広い領域
にわたって透明で，化学的には大きな耐食性を持ち，さ らに，不純物添加により新しい半導体実現の可能性むあ り，また，資源的に見ても極めて豊富な物質である。し たがって，てのような膜が実現可能となれば工業的には 計り知れない用途が開かれてくる。

第 3 はダイヤモンド薄膜を形成する装置の問題であ る。即ち，今まで使用されて来た装置を大別すると，直 流, 高周波, およびマイクロ波を含めたプラズマ法, ガ スのイオン化を利用したイオン化蒸着法またはイオンビ 一ム法，および気相反応を利用した CVD 法などに分類 されるるが, ダイヤモンド薄膜の形にはどの方法が最適 かという装置上の問題がある。

以上のような理由から最近ダイヤモンド薄膜には大き な関心がもたれ注目されている。こてでは中性粒子、イ オン，およびプラズマを利用した各種低温低圧による薄 膜形成法之得られた膜の物性, 構造及び薄膜形成機構に 関する問題点等につきその大要を述べる。

\section{2. 薄膜形成法}

荷電粒子に着目し，従来まで行なわれて来た薄膜形成 法を大別すると，(1) 中性の粒子を利用するすの，(2) プラズマ粒子を利用するすの，（3）イオン粒子を利用す るむのに分けられる。以下これらの装置の実例之得られ た結果につき簡単に述べる。 


\section{1 中性の粒子を利用した装置}

\section{(i) 真空蒸着法}

藤森ら ${ }^{2)}$ は Mo ボートに入れたカーボン, グラファ イト, またはダイヤモンドを $\mathrm{CO}_{2}$ レーザーで加熱蒸発 させ, ダイヤモンド状カーボン膜形成を試みた。得られ た膜の抵抗は蒸発源の材料によって異り，例えば材料が グラファイト粉末の場合は $10^{-2} \Omega \mathrm{cm}$, ダイヤモンド粉 末の場合は $10^{3} \sim 10^{4} \Omega \mathrm{cm}$ と大きく值が違っている。一 方, 結晶構通は電子線の回折結果からアモルファスに近 いカーボン膜であるととが示されている。

(ii) スパッタリング法

この方法は主として Moravec ${ }^{3)}$, Weissmantel ${ }^{4)}$, 平 木5) らによって行なわれて来た。Moravec らが開発し たスパッタリング法を Fig. 1 亿示す。方法は, 約 2,000 $\mathrm{V}$ の負電圧をかけたカーボンターゲットを Ar でスパ ッタし，それぞれのグリットを通して高真空側の基板に 膜を形成しようとしたものである。乙とで，グリットは イオンを中性にするような役目を果している。得られた 膜は比較的硬く, ヌープ硬度で $1,850 \mathrm{~kg} / \mathrm{mm}^{2}$, 屈折率 は $2 \sim 3$, 誘電率は 6 となっており,ダイヤモンドに近 い值を示しているが, 結晶構造はアモルファス状であ る。

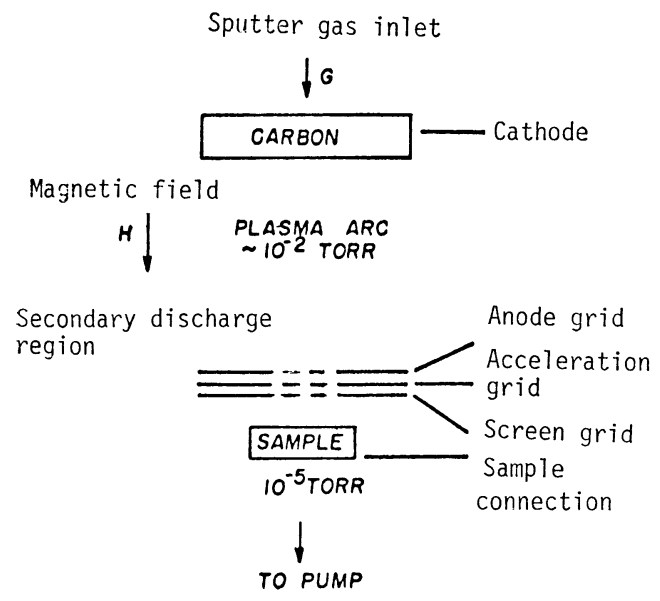

Fig. 1 Sputtering system for cardon films.

Weissmantel らはイオンビームスパッタ法を用い, $10^{-6} \sim 10^{-i} \mathrm{~Pa}$ の高真空中で行なっている。得られた膜 は光学的に透明で, 抵抗率は $10^{11} \Omega \mathrm{cm}$ と大きな值を示 している。膜の構造については AES, RHEED, ESCA 等で調べられているが，乙の段階ではあまり詳細な報告 はまだなされていない。

\section{2 プラズマを利用した装置}

(i) 直流プラズマ法
この種の装置は主として低温プラズマが使用されてい る。低温プラズマということは，ガス中の電子温度のみ が上昇し, ガスイオンの温度は変化しない状態を意味し ている。そこで，てのようなプラズマを利用したカーボ ン膜形成の例を述べる。まず，Fig. 2 は Whitmel ${ }^{6)}$ ら が行なった方法で，前述のスパッタリング法との本質的 な違いは，基板をスパッタ装置のターゲット側に置いて いるところにある。放電に使用されたガスはエチレンに $5 \%$ のアルゴンガスを混合したもので，形成された膜は 非常に硬く, ビッカース硬度で 2,800 以上のものが得ら れている。

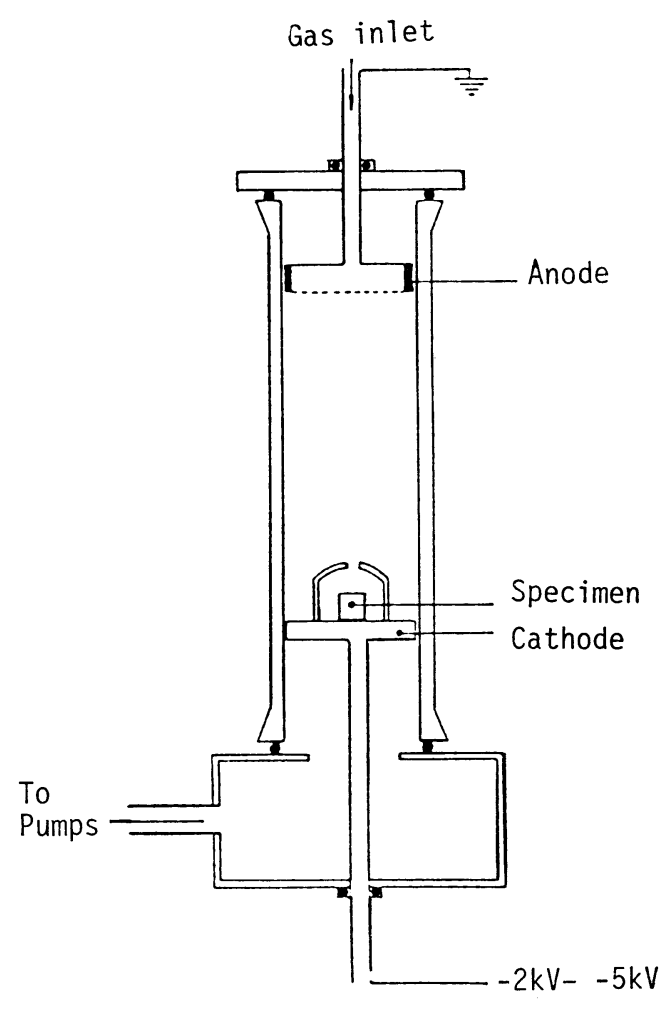

Fig. 2 DC prlsma system.

（ii）高周波プラズマ法

高周波 (13.56 MHz)，または高周波に直流を重畳した 高周波プラズマ法が Moravec ${ }^{7)}$, Zorin ${ }^{8)}$, Bubenzer $^{9)} ら$ により行なわれている。Fig. 3 は1例として Moravec らの方法を示す。膜の結晶構造はこの装置で詳しく調べ られている。用いられたガスはメタン, エタン, プロパ ン, ブタン等で, 圧力は $10^{-1} \mathrm{~Pa}$ となっている。実験は 主として基板温度と高周波電力を変化して行なわれてお り, 電子線回折の結果, 多くのリング状の線が得られて いる。しかし, 膜は (110), (200) 面等からの反射も明瞭 に現われているので，乙の場合はダィヤモンド状という 
Hydrocarbon Gas Inlet

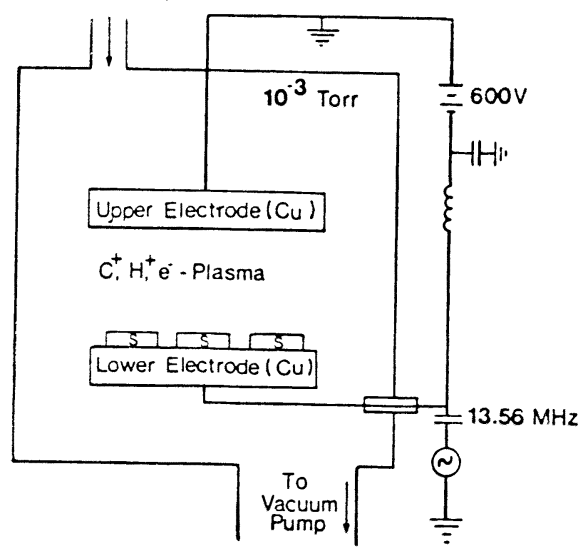

Fig. 3 RF plasma system.

よりは,いわゆる i-C 膜で*ある。

（iii）マイクロ波プラズマ法

周波数をさらに高くし，マイクロ波 $(24.5 \mathrm{GHz})$ 領域 でも同様な実験が行なわれている10)。その装置の1例を

Fig. 4 亿示す。乙の場合, 基板温度は $700 \sim 1,000^{\circ} \mathrm{C}$ で, 得られたものは膜状または粒状で結晶構造はダイヤ モンドであると報告されている。

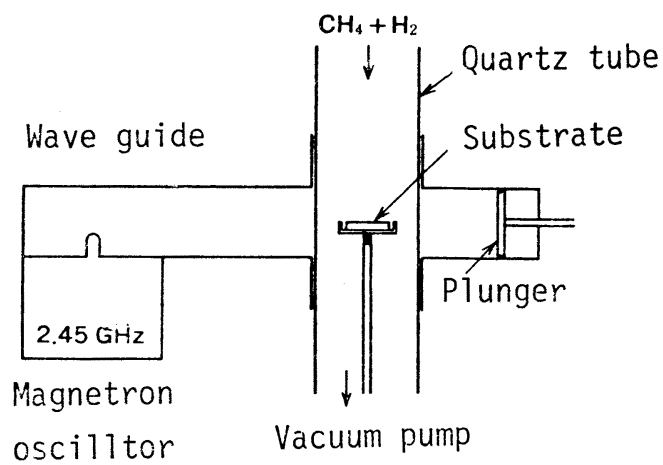

Fig. 4 Micro wave plasma system.

\section{3 イオンを利用した装置}

(i) イオンビーム蒸着法 (IBD)

Fig.5 は Aisenberg'1)らがカー゙ンビームを用いて ダイヤモンド状の膜ができるととを示した装置である。 装置の特長は，放電部分を全てカーボンで構成し，そこ でアルゴンガスによるアーク放電を起させ，発生したカ 一ボンイオンをビーム状に絞り，比較的高い真空度のよ

*i-C は 1979 年に Weissmantel が提唱したカーボン膜で, イオンプレーティング, イオンビーム蒸着等の方法で形 成された硬くて抵抗の大きいカーボン膜のてとを指して いる。したがって，膜は必ずしあダイヤモンド構造であ る必要はない。

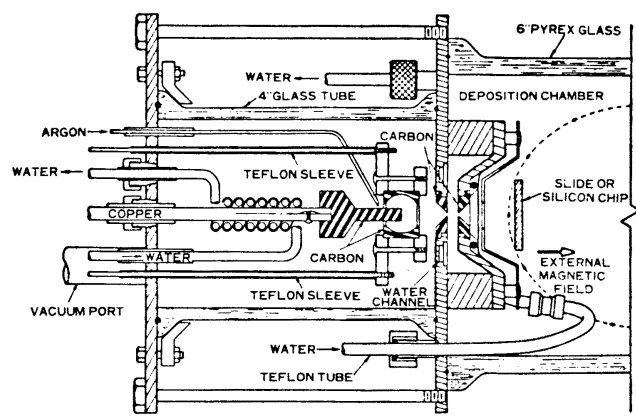

Fig. 5 Ion beam deposition system.

ころで膜の作製を試みたものである。得られた膜は光学 的に透明で，屈折率は 2 , 誘電率は 8 14で非常に硬 く, 高抵抗であることが示されている。膜の構造につい ては Spencer らがこれを追試し11)，ダイヤモンド構造 の膜であるととが確認された。しかし，この場合も Weissmantel ${ }^{12)}$, Moravec ${ }^{7)}$ 等の膜と同様に, ダイヤモ ンドの回折線以外に (100)，(110) 面からの反射が含まれ ているので，ダィヤモンド構造のみで形成された膜とは 云い難い。

（ii）イオン化蒸着法（ID 法）

これは難波らが行なっている方法で13)，Fig.6 は装 置の略図である。この装置は，基本的にはイオンスパッ

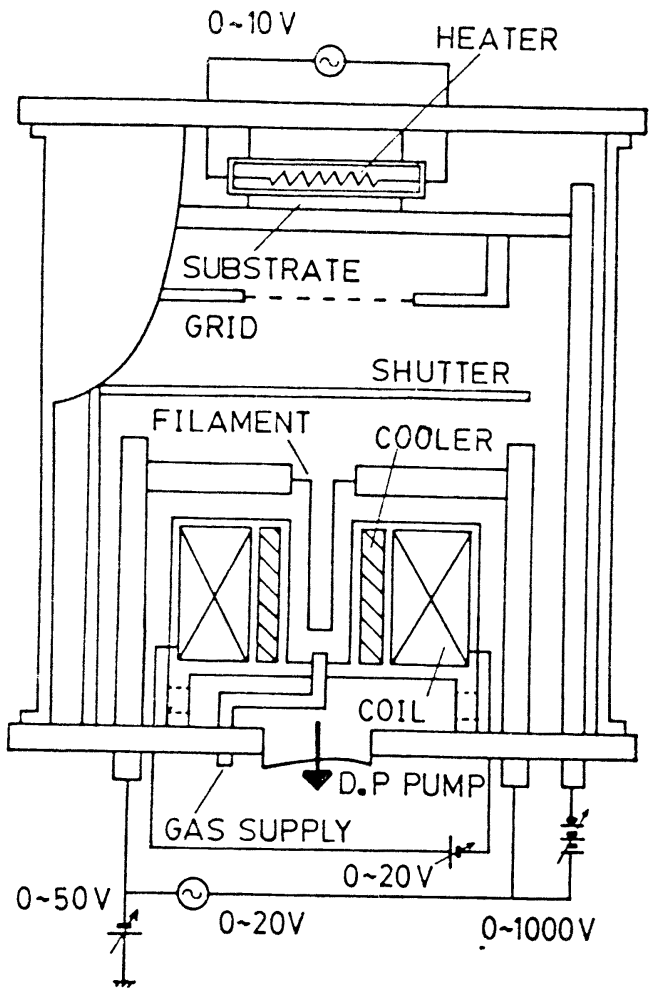

Fig. 6 Ionized deposition system. 
夕蒸着装置であるが，基板がターゲット部分に置かれて いるところが大きく違っている。したがって, 加速電圧 を変えることにより，膜を着けることも削ることも自由 にできるようになっている。

以上，代表的なカーボ膜形成装置について簡単に述 べて来たが, どの装置につしても，電子線回折でダイヤ モンド構造のみを示すような膜はイオン化蒸着法以外に まだ今のところ報告されていない。をてで，乙の装置の 特性, 得られた結果等汇ついてすう少し詳しく述へるこ とにする。

\section{3. 膜の形成と物性}

\section{1 膜の形成条件}

ID 法により形成された膜の性質は膜の形成条件によ り大きく左右される年。。条件の 1 例を示すと下記のよう になる。まず，ガスはメタンガスを用い，圧力は 1〜10 $\mathrm{Pa}$ とし, 基板温度は $200 \sim 500^{\circ} \mathrm{C}$ ，基板電圧は $0 \sim 1,000$ $\mathrm{V}$, イオン電流は 5 10 mA の範囲で変化させ, また, イオン源の方は放電電流を $0.1 \sim 0.4 \mathrm{~A}$, 磁束密度を C $500 \mathrm{G}$ の範囲にとる。乙のような場合, まずイオン源か ら放出されるガスイオンは質量分析の結果 Fig. 7 のよ うになっている。即ち, イオンとしては $\mathrm{H}_{2}^{-}, \mathrm{C}^{+}, \mathrm{CH}^{+}$, $\mathrm{CH}_{2}{ }^{+}, \mathrm{CH}_{3}{ }^{+}, \mathrm{CH}_{4}{ }^{+}$, が含まれているが, 量的には $\mathrm{C}^{+}$は 少なく，大部分は $\mathrm{CH}_{4}{ }^{+}$であると見てよい。乙れらの イオンは基板に向けて加速され, 基板と衝突して分解 し, 条件が満足されればカーボンだけが基板に残り，カ 一ボン膜が形成される。乙の場合蒸着速度は基板電圧や イオン源の磁界によりかなり変化するが, 最高 $20 \AA / \mathrm{sec}$ 程度までの值が得られる。

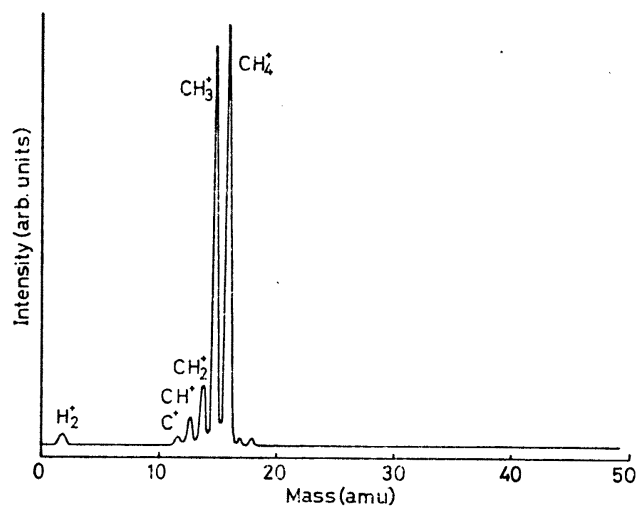

Fig. 7 Mass spectra of ionized methane gas detected by QMS.

\section{2 膜 の性質}

（i ）膜の硬度：Fig. 8 は膜の硬度をビッカース硬度 計で測定した 1 例である。膜は苛さ $1 \mu \mathrm{m}$ で $\mathrm{Si}$ 基板上

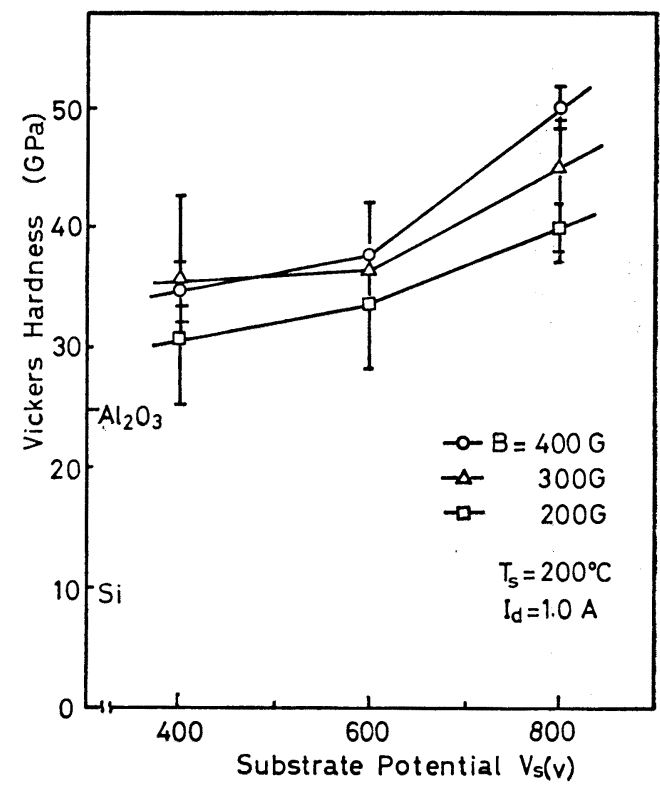

Fig. 8 The relation between the Vickers hardness and substrate potential.

に成長したあのである。形成条件により硬度は $50 \mathrm{GPa}$ 程度まで增加する。なお, 膜は表面につけた傷跡から見 て, サファイヤー, ガラス等の様なむろい膜ではなく, 齐ばりのある膜であるということがわかって来ている。 この事は, 膜が完全にダイヤモンド構造を持つ単結晶で はなく, 一部にアモルファス部分を含み，乙の部分に歪 が吸収される結果と考えられる。

（ii）抵抗率：これは装置及び膜の形成条件により $10^{-2} \sim 10^{14} \Omega \mathrm{cm}$ 程度まで変化する。Fig. 6 のような ID 法で作製した膜は比較的高い值が得られる。Fig. 9 は その 1 例である。とくに, 基板電圧が低いところで形成 した膜は高い抵抗值を示す場合が多い。しかし，てのよ うな膜は抵抗值が高くてもあまり硬度はなく，水素を多 量に含んだポリエチレンに近い膜になっている。

（iii）光学的な性質：光学的性質む形成条件により大 きく変化する。まず, 屈折率は可視光の領域ではダイヤ モンドの 2.4 に近い值が得られている。透過性について

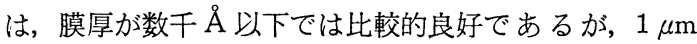
以上の厚みになると不透明になる。色は茶色で, 表面は 滑らかで光沢を有している。Moravec 等は色は膜厚に よって色々変化するとしている。

（iv） 赤外吸収：赤外吸収スペクトルの1例を Fig.10 に示す。試料は, 基板に $400 \mathrm{~V}$ の電圧を加え, 蒸着速 度 $10 \AA / \mathrm{sec}$ で膜 7,000 A まで蒸着し, 測定はプリズム による多重反射で行なったものである。基板温度 $200^{\circ} \mathrm{C}$ の場合は波数が $2,850 \mathrm{~cm}^{-1}$ のところに C-H の 


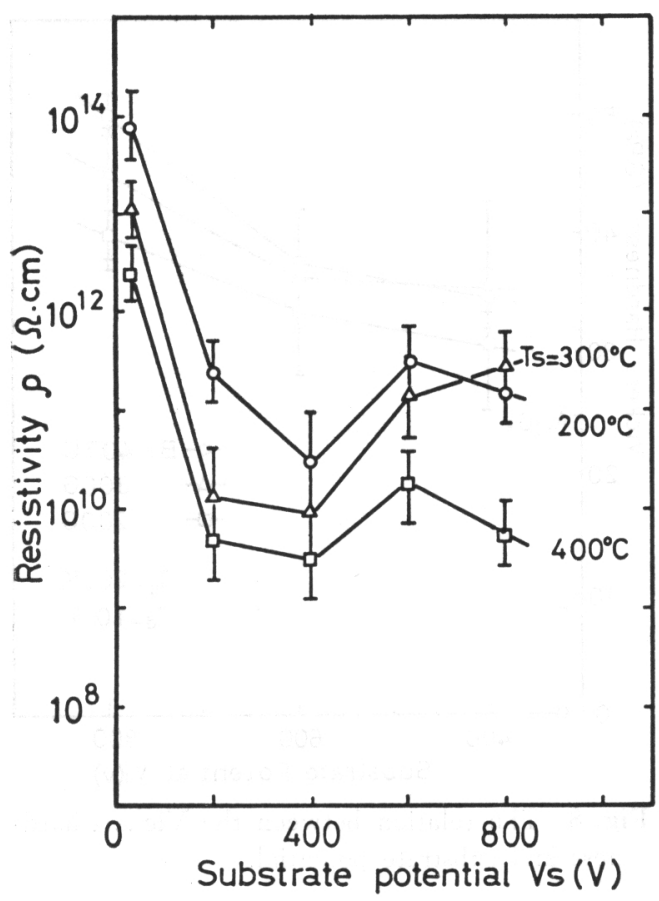

Fig. 9 Resistivity of the diamondlike carbon films.

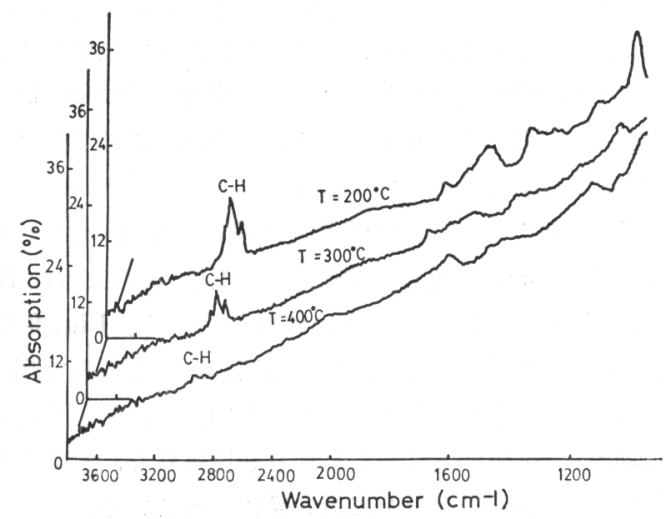

Fig. 10 Infrared absorption of hydrogen distributed in the diamondlike carbon films.

伸縮振動による吸収が認められるが，400C まで高める とこの振動はほとんど消滅していることがわかる。一 方, 膜に含まれる水素を分析した結果, $200^{\circ} \mathrm{C}$ で形成し た膜の水素含有量比で $4.5 \%$ であった。したがって, $400^{\circ} \mathrm{C}$ で形成した膜の水素含有量は $1 \%$ 以下と推定され る。

（v）耐食性：ダイヤモンド状膜の耐食性の 1 例を Fig. 11 に示す。まず (a ) は比抵抗 $0.1 \Omega \mathrm{cm}$ の $\mathrm{Si}(111)$ 面上に形成した厚さ $1 \mu \mathrm{m}$ の膜である。(b) は弗酸と硝 酸を $1: 1$ にした水溶液中に約 5 時間放置したものであ
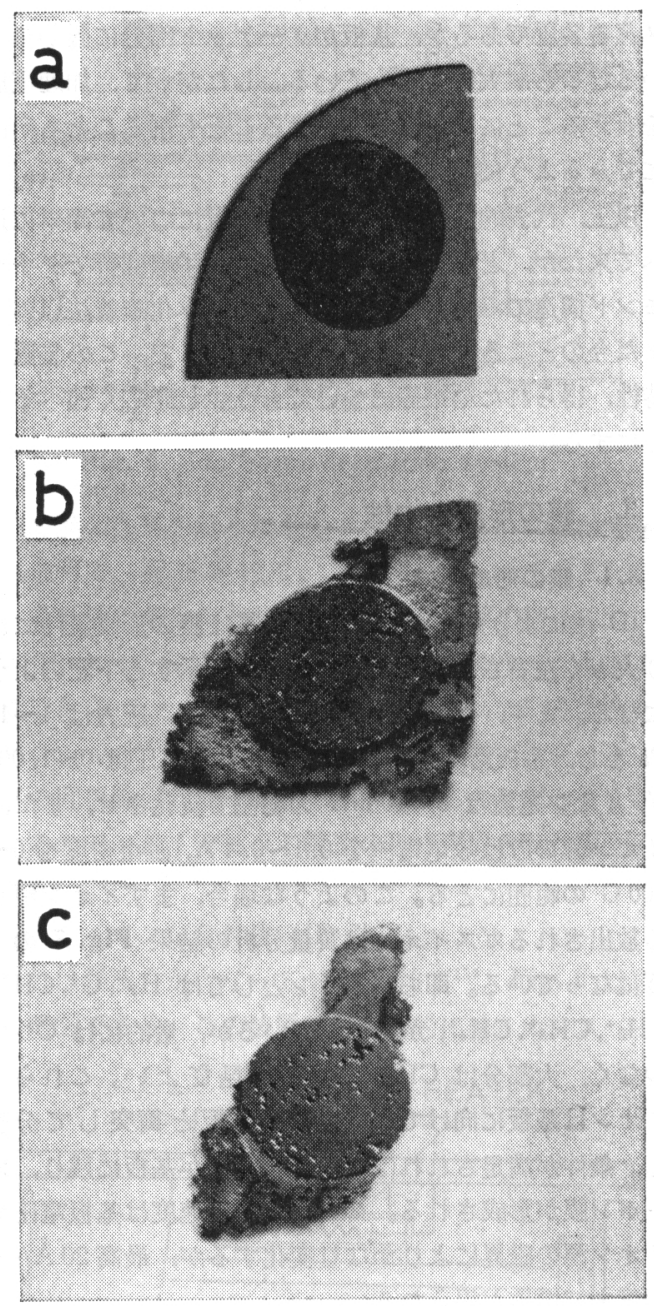

Fig. 11 The disolution of diamondlike carbon film on $\mathrm{Si}$ in a mixed solution of fluoric acid and nitric acid. (a) Original film, (b) after 5 hours, (c) after 10 honrs.

り，(c ）は同じ膜を 10 時間放置したものである。図より Si は溶解されてむ膜の方はほとんど溶解されていない ことがわかる。ただし, 膜の方には多数の腐食孔が発生 して抢り，この孔は何が原因か今のところ不明である。い ずれにしても腐食性はかなり優れていることがわかる。

\section{4. 膜の構 造}

\section{1 表面構造}

走査電子顕微鏡観察によるダイヤモンド状薄膜の断面 及び表面構造の 1 例を Fig. 12 に示す。この膜は基板に $400 \mathrm{~V}$ の電圧を加え, $15 \AA / \mathrm{sec}$ で $\mathrm{Si}$ 基板上に形成した ものであり, ビッカース硬度は $3.2 \mathrm{GPa}$ である。表面 は非常に滑らかであり, 断面あ一様で, 低真空で形成さ れた膜によく見られる柱状構造は見られない。膜の表面 
構造に関しては加速電圧と密接的な関係があり, 常に Fig. 12 の上うな膜が形成されるとは限らない。

\section{2 結晶構造}

(i) グラファイト構造の膜

一般传炭化水素ガスをイオン化し，加速していくと， 基板上に形成された膜はアモルファスから次第に結晶化 していく。乙の場合, 基板の種類, 基板温度, その他蒸 着条件により膜の構造はグラファイト構造をとるかダイ モャンド構造をとるかが決ってくる。この構造を決定す る条件は何かというととに対して明確な答は今のところ

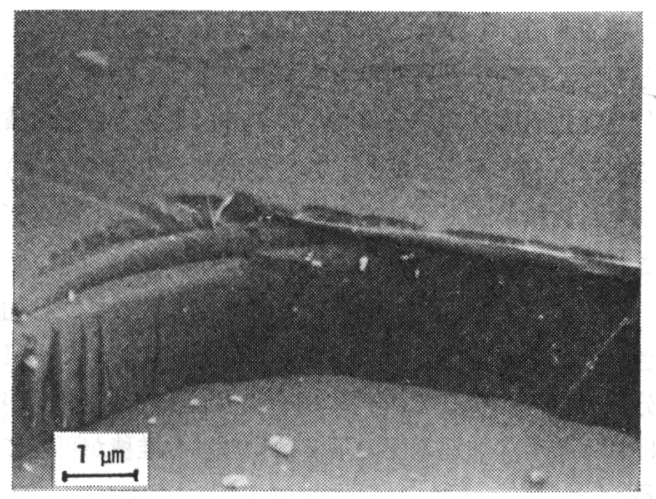

Fig. 12 The cross-sectional structure of diamondlike carbon film.

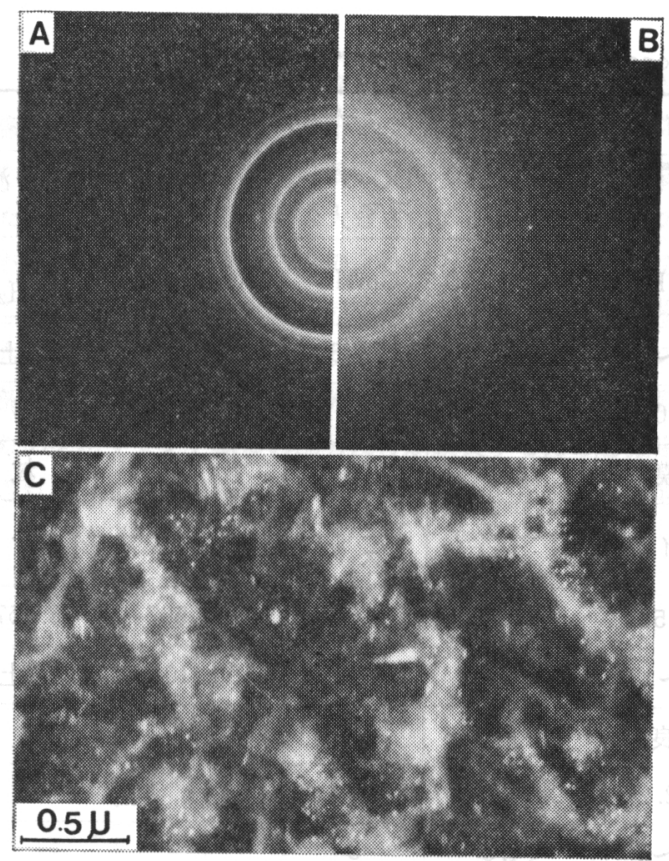

Fig. 13 Electron diffraction patterns of graphite carbon film and graphite powder. (A) graphite carbon film, (B) graphite powder, (C) TEM pattern of graphite film (A).
まだ得られていない。多少明らかになって来た点は，基 板がアモルファスの場合はグラファイト構造に, 単結晶 の場合はダイヤモンド構造汇進む傾向がある。しかし， その他まだ幾つかの要因も考元られるので，との問題は まだ断定できる段階ではない。

Fig. 13(A) はガラス基板を使用し, 基板温度 $200^{\circ} \mathrm{C}$ で形成された膜の TED 像で, 膜は明らかに結晶化して いるととがわかる。Fig. 13(B)のグラファイトパウダー の TED 像と比較すると膜はグラファイト構造になって いるととがわかる。グラファイト構造の詳細は Table 1

Table 1 Interplanar spacings of graphite phase.

\begin{tabular}{cccc}
\hline (hk. 1) & $\begin{array}{c}\text { Graphite } \\
\mathrm{d}(\mathrm{A})\end{array}$ & $\begin{array}{c}\text { ID. Film } \\
\mathrm{d}(\mathrm{A})\end{array}$ & $\begin{array}{c}\text { G. Powder } \\
\mathrm{d}(\mathrm{A})\end{array}$ \\
\hline 00.2 & 3.35 & 3.45 & 3.40 \\
10.0 & 2.13 & 2.13 & 2.13 \\
00.4 & 1.68 & 1.72 & $\ldots \ldots$ \\
11.0 & 1.23 & 1.26 & 1.26 \\
20.0 & 1.07 & 1.07 & $\ldots \ldots$. \\
21.0 & 0.806 & 0.814 & 0.81 \\
30.0 & 0.710 & 0.712 & 0.71 \\
22.0 & 0.615 & 0.615 & $\ldots \ldots$ \\
\hline
\end{tabular}

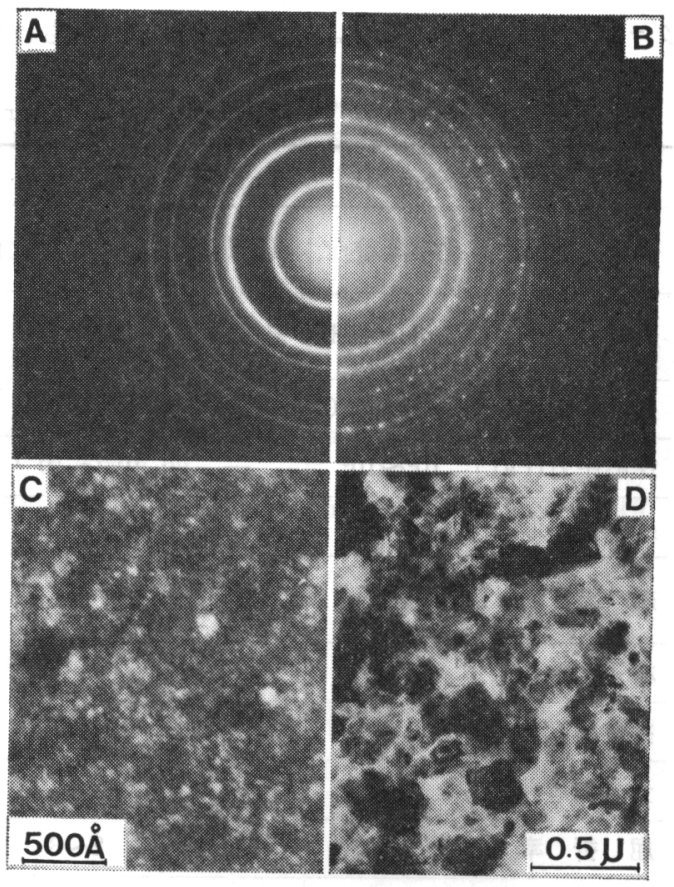

Fig. 14 Electron diffraction pattern of diamondlike film and diamond powder. (A) diamondlike film, (B) diamond powder, (C) TEM pattern of film (A), (D) TEM pattern of powder (B). 
Table 2 Interplanar spacings of diamond phase.

\begin{tabular}{cccc}
\hline (hk. 1) & $\begin{array}{c}\text { Diamond } \\
\mathrm{d}(\mathrm{A})\end{array}$ & $\begin{array}{c}\text { ID. Film } \\
\mathrm{d}(\mathrm{A})\end{array}$ & $\begin{array}{c}\text { D. Powder } \\
\mathrm{d}(\mathrm{A})\end{array}$ \\
\hline 111 & 2.06 & 2.10 & 2.06 \\
220 & 1.26 & 1.26 & 1.26 \\
311 & 1.08 & 1.09 & 1.08 \\
400 & 0.89 & $\ldots \ldots$. & 0.88 \\
331 & 0.81 & 0.81 & 0.81 \\
422 & 0.727 & 0.726 & 0.722 \\
511 & 0.685 & $\ldots \ldots .$. & 0.690 \\
440 & 0.633 & 0.630 & 0.630 \\
\hline
\end{tabular}

に示す通りである。Fig. 13(C) はグラファイトカーボン 膜の TEM 像で, 結晶粒は比較的大きく成長している。

(ii) ダイヤモンド構造の膜

つぎに, $\mathrm{Mg} \odot$ 基板を $200^{\circ} \mathrm{C}$ に加熱し，負電圧を印加 して得た膜の電子顕微鏡像を Fig. 14 に示す。同図で (A)は膜の TED 像で (C) はその TEM 像である。一 方，(B)及び (D) はダイヤモンドパウダーの TED 像及 びその TEM 像である。図(A) 及び (B)の面間隔の詳 細は Table 2 に示す通りで, 計算とも良い一致の得ら れていることがわかる。また，膜の結晶粒の大きさはパ ウダーの值より 1 桁程小さく数百 $\AA$ と推定され, また, グラファイト構造の結晶粒よりかなり小さいとともわか
る。

なお，乙の膜は Spencer, Weissmantel, Vora, Zorin 等により論じられて来た $(100),(110),(200)$, 及び (222) 面からの回折線を含んでおらず，ダイヤモンド結晶によ る回折線のみで構成されている。てのような膜が形成さ れたのは今回が初めてである ${ }^{15) 。}$

\section{5. ダイヤモンド膜の形成機構}

低圧低温中の炭化水素ガスからダイヤモンド薄膜が形 成される機構は不明な点む多く，解明はまだてれからの 問題である。しかし，イオン化蒸着のような場合に多少 とも考え方をま亡めてみるとつぎのようになる。即ち， (i ) 炭化水素ガスが分解しカーボンだけが基板に堆積す る過程，（ii)ダイヤモンドの核が形成する過程，（吕）形 成された核が成長する過程, 以上の過程を経て膜が形成 されるものと考えられる。

そこで, まず( i )の過程に着目すると, ここでは加速 された炭化水素のガスイオンは基板と衝突し， C と $\mathrm{H}$ に 分解するが，そこで C- $\mathrm{H}_{n}$ 結合より C-C 結合の方が強 ければ適当な加速電圧の下ではCだけの堆積が可能にな る。

（ii）の過程はイオンまたは中性の高速分子が基板に衝 突する際に生じる温度及び圧力を調べればある程度の見

Table 3 Typical systems used for diamondlike carbon films and its results.

\begin{tabular}{|c|c|c|c|c|c|c|c|c|}
\hline 飛来粒子 & 中 & 性 & 子 & イ. オ & ン 粒 子 & $フ^{\circ}$ & ズマ 粒 & 子 \\
\hline 手法・励起法 & 化学蒸着 & 真空蒸着 & $\begin{array}{l}\text { スパッタ蒸 } \\
\text { 着 }\end{array}$ & $\begin{array}{l}\text { イオン化 } \\
\text { 蒸着 }\end{array}$ & $\begin{array}{l}\text { イオンビー } \\
\text { ム蒸着 }\end{array}$ & $\begin{array}{l}\mathrm{DC} \text { プラ } \\
\text { ズマ }\end{array}$ & $\begin{array}{l}\mathrm{RF} \\
?\end{array}$ & $\begin{array}{l}\text { マイクロ波 } \\
\text { プラズマ }\end{array}$ \\
\hline 原料・ガス & $\mathrm{CmHn}+\mathrm{H}_{2}$ & $\mathrm{C}$ & $\mathrm{C}, \mathrm{Ar}$ & $\mathrm{CmHn}$ & $\mathrm{CmHn}, \mathrm{CO}$ & $\mathrm{CmHn}$ & $\mathrm{CmHn}+\mathrm{H}_{2}$ & $\begin{array}{l}\mathrm{CmHn} \\
+\mathrm{H}_{2}\end{array}$ \\
\hline 基板温度 $\left({ }^{\circ} \mathrm{C}\right)$ & $700 \sim 1,000$ & - & $\mathrm{RT} \sim 800$ & $\mathrm{RT} \sim 400$ & $\mathrm{RT} \sim 700$ & $\mathrm{RT} \sim 300$ & $700 \sim 1,000$ & 700以上 \\
\hline 反応圧力 $(\mathrm{Pa})$ & $10^{2} \sim 10^{3}$ & - & $10^{-7} \sim 10^{-5}$ & 10 & $10^{-2} \sim 10^{1}$ & $10^{-1} \sim 10$ & $10^{2} \sim 10^{3}$ & $10^{-1} \sim 1$ \\
\hline 生成物の形態 & 膜, 粒 & 膜 & 膜 & 膜 & 膜 & 膜 & 膜, 粒 & 膜, 粒 \\
\hline 結 晶 形 & ダイヤ & $\begin{array}{l}\text { アモルフ } \\
\text { アス }\end{array}$ & $\begin{array}{l}\text { アルファ } \\
\text { ス, ダイヤ }\end{array}$ & ダイヤ & $\begin{array}{l}\text { アルファ } \\
\text { ス, ダイヤ }\end{array}$ & $\begin{array}{l}\text { アモルフ } \\
\text { アス }\end{array}$ & ダイヤ & ダイヤ \\
\hline 格子定数 (A) & 3.567 & - & - & 3.567 &,- 3.567 & 一 & $\sim 3.567$ & $\sim 3.567$ \\
\hline 抵抗率 $(\Omega \mathrm{cm})$ & - & $10^{-2} \sim 10^{3}$ & $10^{11} \sim 10^{12}$ & $10^{8} \sim 10^{11}$ & $10^{6} \sim 10^{14}$ & $10^{8} \sim 10^{11}$ & $10^{8} \sim 10^{11}$ & $10^{9}$ 以上 \\
\hline 光の透過性 & 良 & 良 & 良 & 良 & 良 & 良 & 良 & 良 \\
\hline 屈 折 率 & 2. 38 & - & $2 \sim 3$ & 2.2 & $2.3 \sim 2.4$ & $2.0 \sim 2.8$ & - & - \\
\hline 硬 度 (GPa) & 9.5 & - & $1 \sim 2$ & $2 \sim 5$ & $\therefore<4.5$ & 3 & - & - \\
\hline 主な即究者 & $\begin{array}{l}\text { Derjaguin } \\
\text { Evevsol } \\
\text { 瀬高 }\end{array}$ & 藤森 (進) & $\begin{array}{l}\text { Moravec } \\
\text { Weissman- } \\
\text { tel } \\
\text { 平木 }\end{array}$ & 難 波 & $\begin{array}{l}\text { Freeman } \\
\text { Aiseuberg } \\
\text { 藤森, 権田 }\end{array}$ & Whitmel & $\begin{array}{l}\text { Moravec } \\
\text { Zovin } \\
\text { Bubenzer }\end{array}$ & 瀬＼cjkstart高 \\
\hline
\end{tabular}




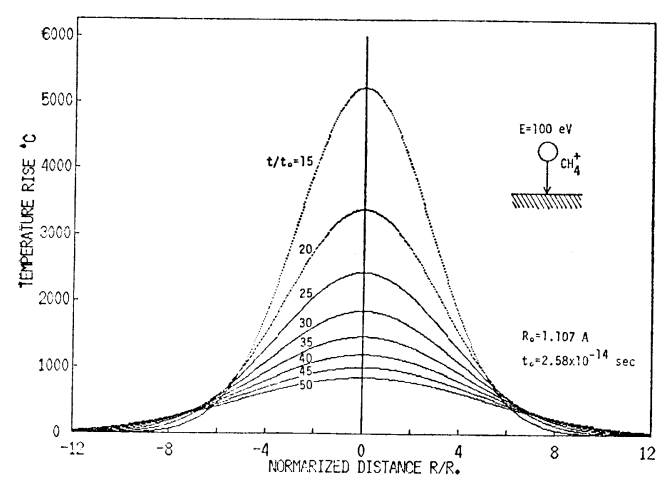

Fig. 15 Temperature rise of the local area on the film surface

$\mathrm{R}$ : mean distance between the two atoms

$t$ : vibration period obtained from Debye Temperature.

当をつけるととが出来る。まず基板を連続体と仮定し, 衝突時の温度上昇を計算すると, 衝突後の時間及び固体 炭素の平均原子間距離に対して Fig. 15 の様な結果が 得られる。圧力変化に対してあまた同様な曲線が得られ る。したがって, $10 \AA$ 程度の炭素原子の結晶粒に着目 すれば, $10^{-12} \mathrm{sec}$ の時間内でダイヤモンドの合成条件 が満足されることになる。即ち, 原子数百個程度よりな るダイヤモンド結晶核の形成はそれ程不自然なととでは ないことになる。

（iiᅭ）の核成長の問題は少々複雑である。まず, TEM 像から，結晶粓は数百〜数干 $\AA$ の大きさになっている ので核成長が行なわれていると見てまず間違いない。ま た, TEM 像から結晶粒の大きさはグラファイト構造の 方がダイヤモンド構造のあのよりはるかに大きい。この ことは, ダイヤモンド構造の核成長が行なわれている場 合, 同時に安定に成長しようとするグラファイト構造の 部分はイオン衝撃等により分解し, 成長が妨げられ, 残 りのダイヤモンド構造の部分だけが成長するためと推定 される。なお核成長に関しては，核がそのままの形で成
長するのか，合体成長しながら大きくなるのか，またて のとき電荷の問題をどう考えるか等, 現在不明の部分が まだ多い。

以上，今まで取扱われて来た代表的な装置，形成され た膜の物性, 構造, 及び形成機構等につき述べて来たが, 最後に今迄の結果を Table 3 にまとめておく。

\section{文 献}

1) S. Aisenberg and R. Chabot: J. Appl. Phys., 42 (1971) 2953.

2) S. Fujimori, T. Kasai, and T. Inamura: Thin Solid Films, 92 (1972) 71.

3) H. Vora and Moravec: J. Appl. Phys., 52 (1981) 615.

4) G. Gautherin and C. Weissmantel: Thin Solid Films, 50 (1980) 135.

5) T. Miyasato, Y. Kawakami, T. Kavano, and A. Hiraki : J. J. Appl. Phys., 23 (4) (1984) L 234.

6) D. S. Whitmell and R. Willamson: Thin Solid Films, 35 (1976) 255.

7) T. J. Moravec and T. W. Orent: J. VAc. Sci. Technol., 18 (1981) 226.

8) E. I. Zorin, V. V. Sukhorukov and D. I. Tetel' baum : Sov. Phys., 25 (1980) 103.

9) A. Bubenzer, B. Dischler, G. Brandt, and P. Koidl : J. Appl. Phys., 54 (8) (1983) 4590.

10) M. Kamo, Y. Sato, S. Matsumoto and N. Setaka: J. Cryst. Growth, 62 (1983) 642.

11) E. G. Spencer, P. H. Schmidt, D. C. Joy, and F. J. Sansalone: Appl. Phys., Lett. 29 (1976) 118.

12) C. Weissmantel. K. Bewiloga, D. Dietlich, H-J. Erler, S. Klose, W. Nowik, and G. Reisse: Thin Solid Films, 72 (1980) 19.

13）毛利敏男, 熊田忠真, 難波義捷 : 表面科学 3 (2) (1982) 75 .

14) T. Mori and Y. Namba: J. Vac. Sci. Technol., 1 (1983) 23.

15) T. Mori and Y. Namba: J. Appl. Phys., 55 (9) (1984) 3276. 